
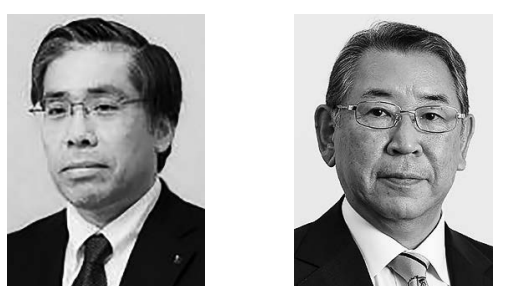

\title{
司会の言葉
}

川内 秀之 ${ }^{1}$, 友田 幸一2

${ }^{1}$ 島根大学

2 関西医科大学

副鼻腔炎に対する有効な治療法として，マクロライド療法や鼻内視鏡手術が1990年代以降急速に発展し人口に膾采し てきました。一方, 初期治療においては一般外来でできる適切な薬物治療や処置が遷延化や慢性化を防ぐ鍵でもありま す。副鼻腔炎の外来で行う治療手段の一つとして, 罹患洞からの排泄をつけるための穿刺やカテーテル治療があります。 慢性副鼻腔炎の発症や増悪，遷延化を防ぐための鼻副鼻腔の換気，排泄の改善を行うこれらの処置は病態形成の観点か らも合理的と言えます。穿刺は，単一副鼻坨を標的とするものですが，カテーテル治療は片側の沉副鼻腔に対する効果 が期待できるという点で優れています。

今回のシンポジウムでは, 最初に, Yonsei大学（韓国, ソウル市）のJoo-Heon Yoon教授に, 正常の粘膜をできるだ け残しながら炎症を制御する機能的治療の基本となる「鼻副鼻腔粘膜の防御機能」について概説していただきます。

次に, 本邦でも保険適応が得られているYAMIKカテーテル®治療の先駆者であるロシア大統領府メディカルアカデ ミーのVladimir Kozlov教授（ロシア，モスクワ市）に，YAMIKカテーテル R治療の原理や開発の経緯，副鼻腔炎治療 への導入と貢献について，日本との交流を含め，お話しいただきます。

その後，特許切れなど諸事情により，本邦での輸入，使用ができなくなったYAMIK®カテーテルに代わって，2014 年に国内でシリコン製ENT-DIBRカテーテルが塚田メディカルにより製造・販売され，継続して保険診療として行え るようになっています。

現在, 副鼻腔炎治療用カテーテル臨床研究会（ENT-DIB研究会）を中心に国内での症例の蓄積が行われています。

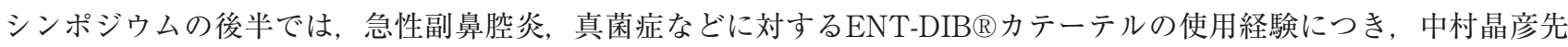
生 (大阪府堺市), 池田浩己先生（和歌山市），飯島正道先生（長野県，上田市）の三人の先生にそれぞれご報告いただ いた後，松根彰志先生（日本医科大学武蔵小杉病院教授）にENT-DIB Rカテーテル処置による，(1)水様性造影剂の副 鼻腔注入の検討結果や，(2)好酸球性副鼻腔炎の術後症例におけるステロイド・生理食塩水による副鼻腔洗浄の試みにつ いて詳細を報告いただきます。

尚, ENT-DIBカテーテルの実際の使用法の展示を学会期間中, 企業展示ブースでおこなっていますのご参照ください。

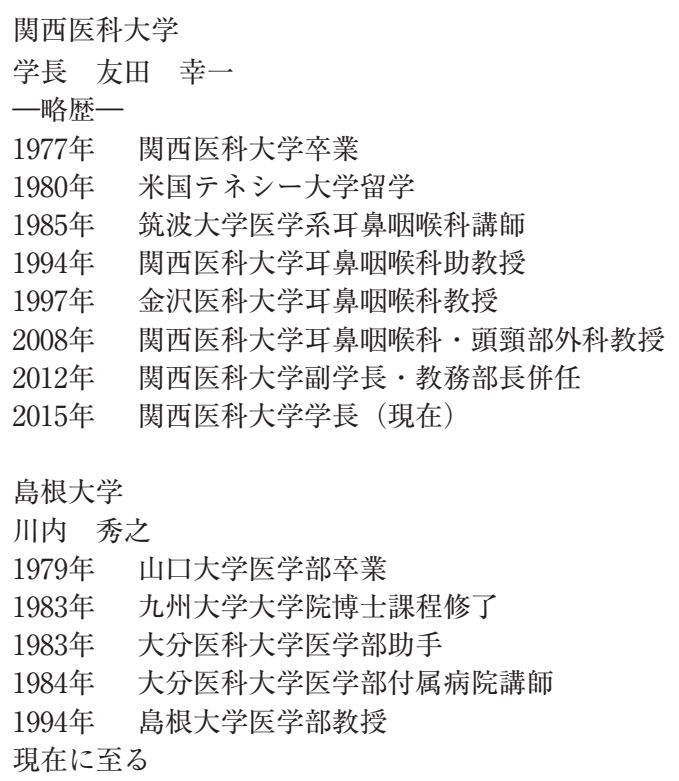




\title{
シンポジウム2
}

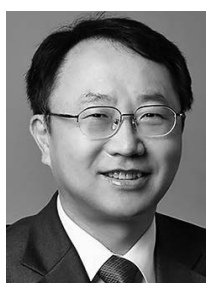

\section{Mucosal Defense Mechanism of the Nose}

\author{
Joo-Heon Yoon
}

Department of Otorhinolaryngology, Yonsei University College of Medicine, Seoul, Korea

Protecting the upper airway from microbial infection or allergens is an important function of the immune system. Airway epithelial hyperplasia and metaplasia result in changes in stored and secreted mucin and the production of a pathologic mucus gel. Mucus transport is impaired, culminating in mucus plugging and airway obstruction. The nasal epithelium is now considered to be central to the orchestration of nasal inflammatory and immune responses, and is also key to tissue remodeling. It acts as the first barrier in the defense against a wide range of inhaled challenges, and is critically involved in the regulation of both innate and adaptive immune responses to these challenges. Recent progress in our understanding of the developmental regulation of this tissue, the differentiation pathways, recognition of pathogens and antimicrobial responses is now exploited to help understand how epithelial cell function and dysfunction contributes to the pathogenesis of a variety of the upper airway diseases. Herein, advances in our knowledge of the biology of airway epithelium, as well as its role and function in upper airway diseases will be presented.

Joo-Heon Yoon,

Professor, Department of Otorhinolaryngology

Director, Global Research Laboratory for Allergic Airway Diseases

Founder. Rhinology Research Forum in Asia (RReFA) since 2015

Yonsei University College of Medicine, Seoul, Korea 


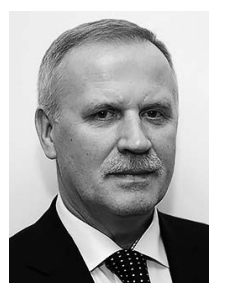

\section{Technology Rhinko. The History and Present State.}

\section{OProf. Dr. VLADIMIR KOZLOV, Dr. STEPAN KUDRYASHOV.}

ENT Department Central State Medical Academy of the Department OF Presidential Affairs, Moscow, Russian Federation.

Paranasal sinusitis (PNS) in the past and present, and well into the future is one of the serious problems in rhinology. Methods of treatment of PNS are divided into conservative and surgical. The widespread use in practice of functional endoscopic sinus surgery (FESS) showed not only advantages, but also revealed notable shortcomings of this method. According to all clinical recommendations, systemic antibiotic therapy remains the main method of treatment for PNS. Given the increase in resistance to antibiotics, this cannot be considered justified. Development of methods of PNS treatment based on local influence in the focal point of inflammation may become a priority research area.

The first publication on the effectiveness of treatment of PNS by creating negative pressure in the nasal cavity was made by P. Gellat in 1911. In 1926, A. Proetz published a method for moving fluids for the purpose of PNS treatment. Both of these methods are based on changing the pressure in the nasal cavity and paranasal sinuses. At the same time, in both methods pressure cannot be controlled. In the period from 1981 to 1992 we developed a method of treatment of PNS, which was based on controlled pressure in the nasal cavity and paranasal sinuses. In the same time frame, five catheter models were developed for which patents of the invention were obtained. To name this method, the acronym "YAMIK" was proposed, which meant "Yaroslavl, Markov and Kozlov". Unfortunately, at present we do not have the right to use this acronym, as in 1991 (unbeknownst to us) it was stolen from us and registered as a trademark.

The first model of the catheter was a three-channel tube on which two balloons were rigidly fixed without the possibility of changing the distance between them. A "working" channel was opening in the space between the balloons (Patent SU1311714A1). The disadvantage of the catheter was that an individual catheter was required for each nose with a specific distance between the balloons. In the second model of the catheter, one of the balloons was made movable which allowed the use of the same catheter for people with different length of the nasal cavity (Patent SU1715327A1). However, the mobility of the balloon was limited, which required to have several types of catheter. In the third model the problem of choosing the distance between the balloons was solved by means of the fact that the tube with the "working" channel was made inside the movable cuff (Patent SU1768141A1). This model was first introduced in Japan at the ISIAN congress in 1991.

At this congress, Prof. Tadami Kumazawa showed interest in our invention. In 1992, Prof. Kumazawa came to Russia together with Dr. Kubo and Dr. Ino. The first international conference dedicated to this method was held in Yaroslavl. Subsequently, in 1993 Prof. Kumazawa sent to us Dr. Nakamura, who within a month fully mastered the method. During one of my visits to Japan, Prof. Kumazawa introduced me to Prof. Goro Mogi, Prof. Masaru Ohyama, Prof. Hiroshi Moriyama, Prof. Hideyuki Kawauchi, Prof. Yuichi Kurono, Prof. Shoji Matsune. In the course of several years we have conducted several training courses for doctors in Tokyo, Kagoshima, Oita, Sendai, Izumo.

The culmination of these visits was the receipt in 1998 of the permission of the Ministry of Health in Japan to use the catheter in clinical practice and its inclusion in the compulsory insurance system. However, the method was designated as a method of washing the nasal cavity, and not as a method of treatment. As a result, it was not beneficial for doctors to use it in practice, whereas the company stopped supplying catheters to Japan.

In 2016, at the ERS congress in Stockholm, Prof. Kawauchi introduced us to Dr. Tsukada. Dr. Tsukada said that in 2014, Japanese colleagues asked him to please start manufacturing catheters, as this method of treatment helps many patients, whereas the Russian company does not supply them. Dr. Tsukada's company has designed a new catheter model called "ENT-DIB.” Indisputably, the key positive point of this model was its manufacture from silicone. The company's engineers introduced a new element into the catheter design, creating an additional channel with a diameter of about $1 \mathrm{~mm}$ inside the tube for inflating the nasopharyngeal balloon, 
which, in their opinion, provided for nasal breathing during the procedure. We really liked the ENT-DIB catheter, especially the quality of implementation and the material from which it was made. Dr. Tsukada presented us with several catheters. Upon returning home, we put them into practice. In process of application it was found that the patient during the procedure cannot breathe through the additional channel, as when the balloon inflates, the channel opening comes in contact with the back of the nasopharynx and is blocked by it. Unfortunately, the ENT-DIB catheter also inherited the drawbacks of the YAMIK catheter. Experimentally, we found that when negative pressure is created in the nasal cavity, the inferior turbinate sharply increases in size (due to the blood supply of thin-walled venous sinusoids), almost reaching the nasal septum and therefore filling the general nasal passage (meatus nasi communis). That is why for some patients, when negative pressure is created, the opening of the "working" channel gets closed by the mucous membrane of the inferior turbinate. The blockade of the opening of the "working" channel does not allow to evacuate the secretion from the paranasal sinuses. To solve this problem, we made design changes to this catheter. In the new model of the catheter, the "working" channel passes in a tube that is made movable relative to the cuff. This design solution allows not only to change the distance between the balloons, but also to bring the tube with the "working" channel directly to the middle nasal meatus. As a result, the opening of the "working" channel cannot be blocked by the inferior turbinate. The new catheter is made of silicone. A patent for an invention was obtained for this catheter (Patent 2663932 dated 13.08.2018; International application No. PCT/ RU2018/000416, dated 22.06.2018).

We have conducted studies of a new catheter, which confirmed the possibility of injecting the radiopaque solution into the paranasal sinuses, as well as the possibility of evacuating the pathological secretion from them in acute rhinosinusitis.

Considering the fact that at present we cannot use the acronym "YAMIK", we propose a new name for the method: Technology "RHINKO".

Kozlov Vladimir Sergeevich

Professor and Chairman of the ENT department for postgraduate education. Central state Medical Academy. General Management Department Under the President of Russian Federation

1974 -1979 Yaroslavl state medical institute, physician faculty

1979 -1981 Clinical post-graduate course on the department otorhinolaryngology of the Yaroslavl state medical institute 1981 -1984 aspirant of the department of otorhinolaryngology of the Yaroslavl medical institute

2006-04.2012 - Professor and Chairman of the ENT Department Central Clinical Hospital. General Management Department Under the President of Russian Federation

1998 - 2006 - Head of the center micro endoscopic otorhinolaryngology of the Yaroslavl Regional Clinical hospital

1998 - 2006 - Professor and Chairman of the department of otorhinolaryngology Yaroslavl State medical Academy

1997 - Ph.D.

1991 - 1998 Head of the center of the Rhinology of Yaroslavl Clinical Hospital

1984 - 1991 assistant professor of the department of otorhinolaryngology of Yaroslavl medical institute

Since 1985 - M.D. 


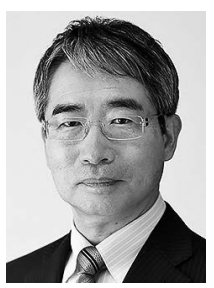

\title{
My Experiences with Catheter Treatment for Sinusitis. - From YAMIK to ENT-DIB-
}

\author{
Akihiko Nakamura
}

Nakamura ENT Clinic, Sakai City, Osaka, Japan

Introduction:

In 1991, Prof. VS Kozlov presented a paper about the YAMIK sinus catheter treatment to Japanese doctors at the $10^{\text {th }}$ ISIAN congress in Tokyo. The acronym YAMIK was derived from Yaloslavl (the name of the City in which they live) and the professor's names, Markov and Kozlov. My colleagues (include late Prof Emeritus Tadami Kumazawa, who sent me to Yaloslavl, Russia, in the terrible winter season), and I were also present at the conference. We learned how to use the catheter and decided to start using it in Japan. For a while, we use the catheter to treat sinusitis, but it could not be used in Japan because of changes in legal regulations in 2002. In 2014, the Tsukada Medical Research Co., Ltd. provided a similar catheter made by silicon at the City of Ueda, Nagano Prefecture. It presented a great opportunity to use new catheters for patients with sinusitis.

Method:

I compared the subjective symptoms of patients with acute and chronic sinusitis using the YAMIK Sinus Catheter with ENT-DIB treatment.

Results:

I have performed over 300 cases of ENT-DIB sinus catheter treatment for patients with sinusitis, which could replace the use of YAMIK sinus catheter in almost all clinical cases, especially in pregnant and lactating women.

Conclusion:

1) I presented the history of recent catheter treatments for sinusitis in Japan.

2) I showed the clinical cases of catheter treatment for sinusitis using the ENT-DIB catheter made by Japanese companies.

3) The ENT-DIB catheter is one of the most useful devices for treatment of patients with acute and chronic sinusitis. 


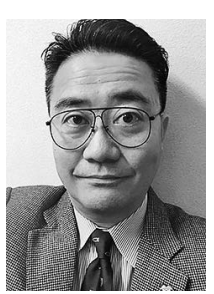

\section{Our Experience of ENT-DIB Sinusitis Therapeutic Catheter}

OHiroki Ikeda ${ }^{1,2}$, Isao Morita ${ }^{2}$, Makoto Miura ${ }^{2}$

${ }^{1}$ Ikeda-Jibika (E.N.T. clinic), Wakayama Japan

${ }^{2}$ Department of Otorhinolaryngology, Japanese Red Cross Wakayama Medical Center

Paranasal sinus washing therapy with the YAMIK catheter began in 1991 in Japan. This therapy was the method that was epochmaking as a paranasal sinus washing therapy to assume Proetz substituted principle. Unfortunately, in Japan, the availability of the YAMIK catheter became difficult in 2005.However, the ENT-DIB sinusitis therapeutic catheter released in Japan In 2014.

This new catheter is expected to show a similar treatment effect to the YAMIK catheter, which is useful as a choice of conservative medical treatment for rhinosinusitis. Briefly, we would like to present the washing method with the ENT-DIB sinusitis therapeutic catheter. First, insert the catheter into the nasal cavity after intranasal gauze anesthesia. Secondly, fix by inflating the balloons around both the nostril and choana. This procedure may change nasal cavity and sinuses into a closed cavity. Finally, wash rhinosinuses with a supine position down to affected side by adding pressurization and depressurization from another channel to rhinosinuses.

This time, we report several cases, including the acute sinusitis, chronic sinusitis, sinus fungal disease, that were performed the washing therapy using the ENT-DIB catheter. This therapy, as an intermediate treatment between surgical therapy and conservative therapy, is considered to be capable of becoming a proactive choice for selected cases. 


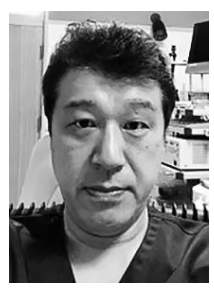

\section{Catheter Treatment for Sisusitis. ENT-DIB Catheter Experience}

Masamichi Iijima

IIJIMA ENT CLINIC Ueda city Nagano, Japan

Introduction: ENT-DIB catheter is a device made by Tukada Medical Reserch

Company for Sinusitis treatment which we can use under Japanese public health insurance since 2014 Jan.1st.I used this device in my clinic for sinusitis treatment, and got some experiences.

Method Case report of some patients. Subjective symptoms of acute sinusitis, treated by ENTDIBcatheter in my clinic, simple washout only by saline, and drug infusion cases.

Results: Acute sinusitis with severe headache was cured by only saline wash. Other case with anosmia (acute) was treated with steroid and antibiotic went better course after ENTDIB treatment.

Conclusion: ENT DIB catheter treatment for acute sinusitis is effective. 


\section{Local Steroid Therapy by ENT-DIB in Eosinophilic Rhinosinusitis After Operation}

Shoji Matsune

Nippon Medical School, Musashikosugi Hospital, Department of Otolaryngology

In acute and chronic rhinosinusitis cases, local therapies such as punctures and catheter therapies have ever been reported and applied in order to improve the clinical effects and/or therapeutic duration as another option except for drug and surgical ones. The mechanisms of the local therapies are to improve the local ventilation and drainage between paranasal sinuses and a nasal cavity. In 1990s, YAMIK® sinus catheter invented initially by Professor Vladimir Kozlov (Russia) prevailed in Japan as the local therapeutic technique for paranasal sinusitis supported by National Healthcare Insurance System. Recently, after expiration of its patency, ENTDib ${ }^{\circledR}$ silicon catheter was produced in Japan as a successor of YAMIK ${ }^{\circledR}$. In our department, ENT-Dib ${ }^{\circledR}$ has already been applied in more than 20 acute and chronic rhinosinusitis cases. In an acute paranasal sinusitis case, not only the clinical effect but also the filling of the contrast agent into paranasal sinuses by CT scan. Additionally, prospective open-randomized clinical study of ENT$\operatorname{Dib}{ }^{\circledR}$ is now going on after the permission by the ethical committee in eosinophilic rhinosinusitis (ERS) in order to assess the irrigation effects in surgically opened sinuses by high-dose steroid once or twice per month after operation. In this session, the ongoing data of this study are mainly to be reported and to discuss the possible position or roll of the local steroid therapy by ENTDib ${ }^{\circledR}$ in ERS. 